\title{
Oxidative Stress in Mongoloids and Caucasians with Type 1 Diabetes
}

Lubov Ilyinichna Kolesnikova ${ }^{1}$, Marina Alexandrovna Darenskaya ${ }^{*}$, Boris Yakovlevich Vlasov ${ }^{1}$, Lyudmila Anatolievna Grebenkina ${ }^{1}$, Natalya Victorovna Semenova ${ }^{1}$, Mariyalgorevna Dolgikh ${ }^{1}$, Tatyana Prokopievna Bardymova ${ }^{1,2}$ and Svetlana Vasilyevna Gnusina ${ }^{1}$

${ }^{1}$ Scientific Centre of the Family Health and Human Reproduction Problems, Siberian Branch, Russian Academy of Medical Sciences, Department of Reproductive Pathophysiology, Russia

2Irkutsk State Medical Academy of Continuing Education Irkutsk, Russia

"Corresponding author: Darenskaya Marina A, Scientific Centre of the Family Health and Human Reproduction Problems, Siberian Branch, Russian Academy of Medical Sciences, Department of Reproductive Pathophysiology, 16, Timiryasev str. Irkutsk. 664003, Russia, Tel: 89642275272; E-mail: mops_my@front.ru

Rec date: Apr 11, 2014, Acc date: May 26, 2014, Pub date: May 29, 2014

Copyright: (c) 2014 Kolesnikova LI, et al. This is an open-access article distributed under the terms of the Creative Commons Attribution License, which permits unrestricted use, distribution, and reproduction in any medium, provided the original author and source are credited.

\begin{abstract}
Objective: It is known that the incidence of type1 diabetes is low among Mongoloid populations. Also, some studies have shown relationship of oxidative stress and this disease. Different parameters of lipid peroxidation and antioxidant defense system, lactate and $\mathrm{Fe}^{2+}$ plasma levels of the same ethnic control groups and groups with type1 diabetes in Mongoloids compared to Caucasians studied in attempt to determine ethnic differences.

Methods: Conjugated dienes, thiobarbituric acid reactants, reduced and oxidized glutathione ratio, total radicaltrapping antioxidant parameter, lactate and $\mathrm{Fe}^{2+}$ levels were evaluated in 65 subjects with type 1 diabetes (38 Mongoloids and 27 Caucasians) and in 82 healthy people (42 Mongoloids and 40 Caucasians). Spectral fluorofotometric methods were used. Statistical analysis was performed by parametric and non-parametric methods.

Results: Lipid peroxidation-antioxidant defense system parameters investigated are not significantly different in ethnic control groups. But, in type 1 diabetes patients mean levels of conjugated dienes, thiobarbituric acid reactants, total radical-trapping antioxidant parameter and ratio of reduced and oxidized glutathione levels were lower in Mongoloids compared to Caucasians. Fe ${ }^{2+}$ level in Caucasians were higher than of Mongoloids. Plasma lactate level in Mongoloids and in Caucasians was higher than in the control groups and in Caucasians higher than in Mongoloids.
\end{abstract}

Conclusion: Ethnicity can play a role in development of oxidative stress in non-compensated type1 diabetes. Perhaps, low incidence of type1 diabetes in Mongoloids is partly due to less lipid peroxidation - antioxidative defense, glucose and $\mathrm{Fe}^{2+}$ metabolic imbalance.

Keywords: Type 1 diabetes; Oxidative stress; Antioxidative defense; Mongoloid; Caucasian

\section{Introduction}

Type 1 diabetes (T1D) is found worldwide and is regarded as one of the main risks to human health [1]. This disorder can be cause of blindness, chronic renal failure, cardiovascular mortality and extremities amputation.

The results of many experimental [2] and clinical studies [3] have suggested that free-radical processes activated during different stages and in different states of T1D [4,5]. Oxidative Stress (OS) in patients with diabetes characterized by elevation of reactive oxygen species production and decrease of Antioxidative Defense (AOD) level that lead to activation of Lipid Peroxidation (LPO) [6] and oxidative lipoprotein modification with increased atherogenesis [7]. Acute hyperglycemia can induce impairment of $\beta$-cells functions with realization of OS and decrease of thioredoxine level [8]. Marra et al. (2002) suggested that T1D patients with a short duration of disease and good metabolic control even in the absence of complications show an early imbalance in their antioxidant capacity and increased of lipid hydroperoxide products levels [9].
Incidence, severity, and rate of complications of T1D are associated with many factors including geographic location and ethnicity. For instance, there is the highest incidence of T1D in Scandinavian countries and the lowest in the East and South-East regions, which with majority of Mongoloid population [10]. We decided to compare LPO-AOD status, lactate and $\mathrm{Fe}^{2+}$ level in Mongoloids and Caucasians with and without T1D living in East Siberia for checking the hypothesis of ethnic factor influence on OS development in patients with T1D.

\section{Methods}

\section{Patients}

The study was conducted in the Scientific Centre of Family Health and Human Reproduction Problems, Siberian Branch of Russian Academy of Medical Sciences (Irkutsk, Russia), in 2011-2013 with ethical standards of Helsinki Declaration (2008). Recruiting patients for the study was in accordance with the negotiability of subjects in the Department of Endocrinology of this Scientific Centre. All participants provided written, informed consent.

We examined 147 persons which were divided into 2 ethnic groups: Mongoloids (ethnic group is buryats) $(\mathrm{n}=80)$ and Caucasians living in 
the modern city Ulan-Ude (East-Siberia) $(n=67)$. Each ethnic group was divided into subgroups: patients with T1D and control.

\section{Inclusion criteria in group with T1D}

Verified diagnosis T1D (diabetes assessment is based on methods and main principles developed by World Health Organization experts in T1D, $2006[11]$ ), insulin replacement therapy, belonging to Caucasians or Mongoloids.

\section{Inclusion criteria in control group}

Absence of T1D in family history.

\section{Exclusion criteria from study}

Severe somatic pathology, severe manifestations of diabetic complications (chronic renal failure, macroangiopathy), exacerbation of chronic diseases, body mass index $>30 \mathrm{~kg} / \mathrm{m}^{2}$.

Group's characteristics are shown in a Table 1. There were no significant differences in sex, age, disease duration, Body Mass Index (BMI), arterial pressure in T1D group. There was triacilglycerole elevation in the ethnic groups compared to controls. Diabetic and control subjects were also well-matched for diet habits, in terms of fruit and fresh vegetables consumption. As previously validated dietary information was obtained by trained interviewers from in a questionnaire whose principles have been previously described. There were no significant differences in diet habits and physical activity between the patients of both ethnic groups. All participants reported only occasional alcohol intake; of the 38 Mongoloids patients only 6 reported smoking occasionally and of the 27 Caucasians patients only 4 reported smoking occasionally.

\begin{tabular}{|c|c|c|c|c|}
\hline \multirow[t]{2}{*}{ Clinical Data } & \multicolumn{2}{|l|}{ Mongoloids } & \multicolumn{2}{|l|}{ Caucasians } \\
\hline & $\begin{array}{l}\text { T1D } \\
(n=38)\end{array}$ & $\begin{array}{l}\text { Control } \\
\text { group } \\
(n=42)\end{array}$ & $\begin{array}{l}\text { T1D } \\
(n=27)\end{array}$ & $\begin{array}{l}\text { Control } \\
\text { group } \\
(n=40)\end{array}$ \\
\hline Men/women (n) & $15 / 23$ & $22 / 20$ & $15 / 12$ & $20 / 20$ \\
\hline Age (years) & $34.4 \pm 11.7$ & $31.4 \pm 8.0$ & $32.7 \pm 11.9$ & $27.8 \pm 7.7$ \\
\hline $\begin{array}{l}\text { Cigarette smoking } \\
\text { (n) }\end{array}$ & 6 & 5 & 4 & 6 \\
\hline $\begin{array}{l}\text { Duration of disease } \\
\text { (years) }\end{array}$ & $12.1 \pm 3.5$ & - & $12.9 \pm 4.0$ & - \\
\hline $\mathrm{Hb} \mathrm{A} \mathrm{A}_{1 \mathrm{C}}(\%)$ & $9.29 \pm 3.06$ & $4.41 \pm 0.72$ & $8.74 \pm 2.24$ & $4.92 \pm 0.52$ \\
\hline BMI (kg/m²) & $23.6 \pm 3.1$ & $21.3 \pm 2.3$ & $25.8 \pm 4.1$ & $22.5 \pm 3.6$ \\
\hline $\begin{array}{l}\text { Cholesterol } \\
(\mathrm{mmol} / \mathrm{l})\end{array}$ & $4.75 \pm 1.19$ & $4.30 \pm 1.32$ & $5.67 \pm 1.24$ & $4.25 \pm 1.24$ \\
\hline $\begin{array}{l}\text { Triacilglycerols } \\
(\mathrm{mmol} / \mathrm{l})\end{array}$ & $1.02 \pm 0.68$ & $0.68 \pm 0.22$ & $1.55 \pm 0.76$ & $0.56 \pm 0.21$ \\
\hline $\begin{array}{l}\text { Systolic } \quad \text { blood } \\
\text { pressure }(\mathrm{mm} \mathrm{Hg})\end{array}$ & $116 \pm 12$ & $117 \pm 13$ & $118 \pm 11$ & $116 \pm 10$ \\
\hline $\begin{array}{l}\text { Diastolic } \quad \text { blood } \\
\text { pressure }(\mathrm{mm} \mathrm{Hg})\end{array}$ & $74 \pm 13$ & $72 \pm 11$ & $75 \pm 10$ & $76 \pm 12$ \\
\hline
\end{tabular}

Table 1: Baseline characteristics of diabetic and control subjects

\section{Assessment}

Patient's blood samples were collected after 12-hours of overnight fasting, centrifuged for $5 \mathrm{~min}$ at $1.500 \mathrm{~g}$ at $4^{\circ} \mathrm{C}$, and erythrocytes were washed three times with $\mathrm{NaCI} 0.9 \%$ (wt/vol). Aliquots of ethilenediaminetetraacetic acid plasma and washed erythrocytes were used immediately or kept frozen in $-40^{\circ} \mathrm{C}$, but not more than one month.

The concentration of Conjugated Dienes (CDs) absorbance detected on of plasma heptanes extracts at $232 \mathrm{~nm}$ [12]. Coefficient of molar absorption $\left(\mathrm{K}=2.2 \times 10^{5} \mathrm{M}^{-1} \mathrm{C}^{-1}\right)$ for conversion of absorption units to $\mathrm{mmol} / \mathrm{l}$ was used. Thio Barbituric Acid Reactants (TBARs) levels were detected by fluorometry [13] end estimated in mmol/l. Activity of AOD system was assessed on total radical-trapping antioxidant parameter (TRAP) level, which was measured by nosubstrate method on 2,2'-azinobis-(3-ethylbensothazoline-6sulphonate) radical cation formation (absorbance at $734 \mathrm{~nm}$ ) in the presence of exogenous $\mathrm{H}_{2} \mathrm{O}_{2}$ [14]. Water soluble vitamin $\mathrm{E}$ analog, Trolox (6-hydroxy-2,5,7,8-tetramethylchroman-2-carboxylic acid) for standardization of analytic procedure was used. Fluorometry for reduced (GSH) and oxidized (GSSG) glutathione levels in hemolysate [15] have been used. Plasma lactate level was determined by spectrophotometry with using the LOX-PAP kits (Biocon, Germany) and given in $\mathrm{mmol} / \mathrm{l}$.

Plasma $\mathrm{Fe}^{2+}$ level were obtained with using spectrophotometric assay «IRON liquicolor» (Human, Germany) by biochemical analyzer «BTS-330» (BioSistems, Spain).

\section{Statistical analysis}

Statistical analysis was performed by STATISTICA6.1 software (Stat-Soft Inc., USA). Means and standard deviation of means were calculated and significance of differences between values was evaluated by Student (T-test) and Mann-Whitney (U-test). The level of significance was set at $\mathrm{p}<0.05$.

\section{Results}

CDs levels were elevated by $27.5 \%$ in Mongoloids with T1D $(\mathrm{P}<0.05)$ and by $71.8 \%$ in Caucasians with T1D $(\mathrm{P}<0.001)$ compare to the control groups (Table 2). CDs level was higher in Caucasians with T1D than in Mongoloids with T1D by $46.1 \%(\mathrm{P}<0.001)$.

TBARs level in Mongoloids with T1D was similar to the control group $(\mathrm{P}>0.05)$, but in Caucasians with $\mathrm{T} 1 \mathrm{D}$ was by $51.1 \%$ higher $(\mathrm{P}<0.001)$ than in healthy people and by $24.3 \%$ higher $(\mathrm{P}<0.05)$ than in Mongoloids with T1D. TRAPs levels in the patients with T1D of the both ethnic groups was decreased (Table 2). TRAPs level in Mongoloids with T1D were lower by $31.69 \%(\mathrm{P}<0.001)$ and in Caucasians with T1D by $38.48 \%(\mathrm{P}<0.001)$ compare to controls. We also found that TRAPs levels in Caucasians with T1D were lower by $7.5 \%(\mathrm{P}<0.01)$ than in Mongoloids patients.

GSH/GSSG levels in Mongoloids with T1D was similar to the control group $(\mathrm{P}>0.05)$ and significantly decreased by $25 \%$ in Caucasians with T1D $(\mathrm{P}<0.05)$ compare to healthy persons.

Plasma lactate level in Mongoloids with T1D was by $28.7 \%$ and in Caucasians with T1D by $131.5 \%$ higher than in the control groups $(\mathrm{P}<0.05$ and $\mathrm{P}<0.001$ correspondently) and in Caucasians with $\mathrm{T} 1 \mathrm{D}$ by $17.7 \%$ higher than in Mongoloids with T1D $(\mathrm{P}<0.01)$ (Table 3$)$. 
Plasma $\mathrm{Fe}^{2+}$ level was elevated both in Mongoloids with T1D (by $60.2 \%, \mathrm{P}<0.001$ ) and in Caucasians with T1D (by 63.1\%, $\mathrm{P}<0.001$ ) compare to healthy people (Table 3). We also found differences in $\mathrm{Fe}^{2+}$ levels between the ethnic groups - $16.2 \%$ higher $(\mathrm{P}<0.01)$ in Caucasians than Mongoloids ones.

\begin{tabular}{|c|c|c|c|c|c|c|}
\hline \multirow[t]{2}{*}{ Parametrs } & \multicolumn{2}{|c|}{ Mongoloids } & \multirow[t]{2}{*}{$P$ value } & \multicolumn{2}{|c|}{ Caucasians } & \multirow[t]{2}{*}{$P$ value } \\
\hline & $\begin{array}{l}\text { T1D } \\
(n=38)\end{array}$ & $\begin{array}{l}\text { Control } \\
\text { group } \\
(n=42)\end{array}$ & & $\begin{array}{l}\text { T1D } \\
(n=27)\end{array}$ & $\begin{array}{l}\text { Control } \\
\text { group } \\
(n=40)\end{array}$ & \\
\hline $\begin{array}{l}\text { CDs } \\
(\mu \mathrm{mol} / \mathrm{l})\end{array}$ & $\begin{array}{ll}1.67 & \pm \\
0.75 & \end{array}$ & $\begin{array}{ll}1.31 & \pm \\
0.65 & \end{array}$ & $\mathrm{p}_{1}<0.05$ & $\begin{array}{ll}2.44 & \pm \\
1.26 & \end{array}$ & $\begin{array}{l}1.42 \\
0.78\end{array}$ & $\begin{array}{l}\mathrm{p}_{2}<0.001 \\
\mathrm{p}_{3}<0.01\end{array}$ \\
\hline $\begin{array}{l}\text { TBARs } \\
(\mu \mathrm{mol} / \mathrm{l})\end{array}$ & $\begin{array}{ll}1.69 & \pm \\
0.71 & \end{array}$ & $\begin{array}{ll}1.42 & \pm \\
0.66 & \end{array}$ & & $\begin{array}{ll}2.10 & \pm \\
0.66 & \end{array}$ & $\begin{array}{ll}1.39 & \pm \\
0.69 & \end{array}$ & $\begin{array}{l}\mathrm{p}_{2}<0.001 \\
\mathrm{p}_{3}<0.05\end{array}$ \\
\hline $\begin{array}{l}\text { TRAP } \\
(\mu \mathrm{mol} / \mathrm{l})\end{array}$ & $\begin{array}{l}623.88 \\
\pm 6.85\end{array}$ & $\begin{array}{l}913.26 \pm \\
7.43\end{array}$ & $\mathrm{p}_{1}<0.001$ & $\begin{array}{l}577.03 \\
\pm 47.72\end{array}$ & $\begin{array}{l}937.88 \pm \\
45.22\end{array}$ & $\begin{array}{l}\mathrm{p}_{2}<0.001 \\
\mathrm{p}_{3}<0.01\end{array}$ \\
\hline GSH/GSSG & $\begin{array}{ll}1.49 & \pm \\
0.70 & \end{array}$ & $\begin{array}{ll}1.62 & \pm \\
0.58 & \end{array}$ & & $\begin{array}{ll}1.20 & \pm \\
0.32 & \end{array}$ & $\begin{array}{ll}1.50 & \pm \\
0.66 & \end{array}$ & $\mathrm{p}_{2}<0.05$ \\
\hline
\end{tabular}

Table 2: LPO and AOD values in Mongoloids and Caucasians with T1D

\begin{tabular}{|c|c|c|c|c|c|c|}
\hline \multirow[t]{2}{*}{ Parameter } & \multicolumn{2}{|c|}{ Mongoloids } & \multirow[t]{2}{*}{$P$ value } & \multicolumn{2}{|c|}{ Caucasians } & \multirow[t]{2}{*}{$P$ value } \\
\hline & $\begin{array}{l}\text { T1D } \\
(n=38)\end{array}$ & $\begin{array}{l}\text { Control } \\
\text { group } \\
(n=42)\end{array}$ & & $\begin{array}{l}\text { T1D } \\
(n=27)\end{array}$ & $\begin{array}{l}\text { Control } \\
\text { group } \\
(n=40)\end{array}$ & \\
\hline $\begin{array}{l}\text { Lactate, } \\
\mathrm{mmol} / \mathrm{l}\end{array}$ & $\begin{array}{l}1.75 \pm \\
0.31\end{array}$ & $\begin{array}{ll}1.36 & \pm \\
0.47 & \end{array}$ & $\mathrm{p}_{1}<0.05$ & $\begin{array}{l}2.06 \pm \\
0.56\end{array}$ & $\begin{array}{ll}0.89 & \pm \\
0.31 & \end{array}$ & $\begin{array}{l}\mathrm{p}_{2}<0.001 \\
\mathrm{p}_{3}<0.01\end{array}$ \\
\hline $\begin{array}{l}\mathrm{Fe}^{2+}, \\
\mu \mathrm{mol} / / \mathrm{l}\end{array}$ & $\begin{array}{l}21.18 \pm \\
4.12\end{array}$ & $\begin{array}{l}13.22 \pm \\
1.23\end{array}$ & $\mathrm{p}_{1}<0.001$ & $\begin{array}{l}25.28 \\
\pm 4.32\end{array}$ & $\begin{array}{l}15.50 \quad \pm \\
3.35\end{array}$ & $\begin{array}{l}\mathrm{p}_{2}<0.001 \\
\mathrm{p}_{3}<0.01\end{array}$ \\
\hline
\end{tabular}

Table 3: Plasma lactate and $\mathrm{Fe}^{2+}$ level in patients with T1D

$\mathrm{p}_{1}$ - significant difference between Mongoloid control and Mongoloid group with T1D; $\mathrm{p}_{2}$ - significant difference between Caucasian control and Caucasian group with T1D; $\mathrm{p}_{3}-$ significant difference between both ethnic groups with T1D

\section{Discussion}

It is well known that OS is characterized by redox imbalance with isolated or combined changes in concentration of pro- or antioxidative substances. The results of our research demonstrate significantly higher CDs levels in Caucasians with T1D compare to Mongoloids. The increase CDs generation induces abnormal permeability of cell membranes for ions, electrolytes and macromolecules. This effect underlies many of the pathogenic mechanisms including diabetic vascular disorders induced by LPO during continuous hyperglycemia [16]. Moreover, high concentration of lipid hydroperoxides, which also contain conjugated links, decreases as a result of intensive insulin treatment in T1D [17].

Also, we found that TBARs level was higher in Caucasians than in Mongoloids with T1D. TBARs compounds can develop nonenzyme modification of cells components in reactions with aminogroups of intracellular proteins, nitrogenous bases of DNA and other molecules
[18]. It is suggested that high concentration of TBARs can cause carbonyl modification of hemoglobin. Moreover, TBARs modify sulfhydryl groups in some redox-sensitive molecules leading to their impairment [19].

However, mammals have specific enzyme systems for neutralization of carbonil compounds, for instance, aldo-ketoreductases that take part in diabetic complications [20]. It should be noted that this enzyme implicates in diabetes pathogenesis only in cases of high continuous hyperglycemia (activation of polyoilic way) [21]. In this way, inhibitors of aldose reductase could be a perspective factor for prevention of diabetic complications [22].

Thus, elevation of CDs and TBARs levels in Caucasian patients with diabetes compare to Mongoloids confirms activation of pro-oxidative processes during lipid peroxidation.

Isolated increases of LPO activity doesn't contain complete information about redox state in ethnic patients with T1D. We also assessed theirs AOD state and TRAP level as an integrated indicator of AOD [23]. We found decrease its values in Caucasians compare to Mongoloids with T1D. This fact in the Caucasian patients may be explained as decreasing of hydrogen-donating ability of plasma due to high consumption of antioxidants for neutralization of LPO intermediates. Our data confirm significant decrease of GSH/GSSG level in Caucasians compare to Mongoloids with T1D. It is well known that GSH/GSSG level is the sensitive indicator of redox trend of metabolism [24], especially in a view of the fact that tissue glutathione concentration is hundreds times higher than other antioxidants [25]. Interestingly, that enzymatic detoxification of these compounds can be activated by binding to GSH, which indicates crosstalk between the GSH redox system and aldo-keto reductases system [26]. Of course, this kind of binding leads to a decrease of GSH/GSSG level.

Furthermore, in reality of angiopathy, even in compensated T1D, we suggest that these metabolic disorders should be attended by circulative and tissue hypoxia with anaerobic glycolysis activation and increase of plasma lactate level. Lactate is one of the earliest and the most significant laboratory predictors of hypoxia, because of it concentration increases before appearing of hemodynamic and other metabolic signs of hypoxia [27]. Also of interest, in anesthetized healthy experimental animals lactate injection causes increased insulin resistance in skeletal muscles [28].

We observed increase lactate concentration in the patients with T1D of both ethnic groups comparing to healthy people. However, there were significant differences such as: 1) base lactate levels in healthy Mongoloids was higher than in healthy Caucasians, 2) in the cases of T1D lactate gains in Mongoloids was significantly less than in Caucasians 3) in the cases of T1D, concentration of final plasma glycolysis metabolites was higher in Caucasians than in Mongoloids. Thus, more significant increases in lactate concentrations and its higher blood levels in Caucasians with T1D indicates an anaerobic tendency of their metabolism with acidosis development. We would like to emphasize that elevation of lactate level in Caucasians with T1D intends to increase glycolysis intermediates. Some of its may be related to TBARs (hexa-and triose phosphates, pyruvate) with its negative influence on redox state in T1D [29].

It is known that decreased $\mathrm{pH}$ leads to increase plasma $\mathrm{Fe}^{2+}$ level. $\mathrm{Fe}^{2+}$ may be preceded from lactoferrin or transferring depo [30] and gives rise to different free-radical processes through the Fenton reaction [31]. Increase of plasma $\mathrm{Fe}^{2+}$ level in Caucasians with T1D compare to Mongoloids with T1Dis consistent with the data of the last 
reviews concerning these biochemical relations. Lactate elevation and decrease $\mathrm{pH}$ with increase plasma $\mathrm{Fe}^{2+}$ level may lead to vascular disorders.

In our work we did not divide patients with T1D by level of glucose that is limitation of present study. Also, we are going to carry out a regression analysis in the next work which allows seeing what influences the development of oxidative stress in patients with T1D.

\section{Conclusions}

We suppose that ethnic factor plays one of the most important roles in development of oxidative stress in non-compensated T1D. However, ethnic factor does not play role in lipid peroxidation in healthy people. Perhaps, low incidence of type 1 diabetes in Mongoloids due to less lipid peroxidation-antioxidative defense, glucose and $\mathrm{Fe}^{2+}$ metabolic imbalance. Further studies in this area can give more opportunities for developing specific approaches of diagnostics, prophylactic and treatment of T1D in patients of different ethnic groups.

\section{Acknowledgement}

This study was supported by a grant from President of Russian Federation (NO-5646.2014.7). There is no conflict of interest.

For special revision of the English language in the manuscript we thank Nicholas Brown, Masters in Science via Research in Neuroscience from the University of Edinburgh (MSc), Masters in the Arts in Cognition and Culture from Queens University Belfast (MA).

\section{References}

1. Ludvigsson J (2006) Why diabetes incidence increases--a unifying theory. Ann N Y Acad Sci 1079: 374-382.

2. Maritim AC, Sanders RA, Watkins JB 3rd (2003) Diabetes, oxidative stress, and antioxidants: a review. J Biochem Mol Toxicol 17: 24-38.

3. Martín-Gallán P, Carrascosa A, Gussinye M, Domínguez C (2005) Estimation of lipoperoxidative damage and antioxidant status in diabetic children: relationship with individual antioxidants. Free Radic Res 39: 933-942.

4. Martín-Gallán P, Carrascosa A, Gussinyé M, Domínguez C (2003) Biomarkers of diabetes-associated oxidative stress and antioxidant status in young diabetic patients with or without subclinical complications. Free Radic Biol Med 34: 1563-1574.

5. Takayanagi R, Inoguchi T, Ohnaka K (2011) Clinical and experimental evidence for oxidative stress as an exacerbating factor of diabetes mellitus. J Clin Biochem Nutr 48: 72-77.

6. Kolesnikova LI, Petrova VA, Darenskaya MA, Dolgikh MI, Grebenkina LA (2006) Changes of lipid metabolism in diabetes mellitus in different age periods of reproductive system formation. Chinese journal of Pathophysiology 22: 202.

7. Taskinen MR (2003) Diabetic dyslipidaemia: from basic research to clinical practice. Diabetologia 46: 733-749.

8. Miyazaki Y, Kawano H, Yoshida T, Miyamoto S, Hokamaki J, et al. (2007) Pancreatic B-cell function is altered by oxidative stress induced by acute hyperglycaemia. Diabet Med 24: 154-160.

9. Marra G, Cotroneo P, Pitocco D, Manto A, Di Leo MA, et al. (2002) Early increase of oxidative stress and reduced antioxidant defenses in patients with uncomplicated type 1 diabetes: a case for gender difference. Diabetes Care 25: 370-375.

10. Alexeev L, Boldyreva M, Trofimov D (1996) HLA genetic markers of T1D in Bur?at population. Human Immunol 47: 156.
11. World Health Organization (2006) Definition, Diagnosis and Classification of Diabetes Mellitus and its Complications: Report of a WHO Consultation. Geneva (Switzerland): WHO, 2006.

12. Santini SA, Marra G, Giardina B, Cotroneo P, Mordente A, et al. (1997) Defective plasma antioxidant defenses and enhanced susceptibility to lipid peroxidation in uncomplicated IDDM. Diabetes 46: 1853-1858.

13. Yagy K (1982) Lipid Peroxides in Biology and Medicine. New York, Academic Press.

14. Rice-Evans C, Miller NJ (1994) Total antioxidant status in plasma and body fluids. Methods Enzymol 234: 279-293.

15. Hissin PJ, Hilf R (1976) A fluorometric method for determination of oxidized and reduced glutathione in tissues. Anal Biochem 74: 214-226.

16. Kaviarasan K1, Arjunan MM, Pugalendi KV (2005) Lipid profile, oxidant-antioxidant status and glycoprotein components in hyperlipidemic patients with/without diabetes. Clin Chim Acta 362: 49-56.

17. Berg TJ, Nourooz-Zadeh J, Wolff SP, Tritschler HJ, Bangstad HJ, et al. (1998) Hydroperoxides in plasma are reduced by intensified insulin treatment. A randomized controlled study of IDDM patients with microalbuminuria. Diabetes Care 21: 1295-1300.

18. Rabinovitch A, Suarez-Pinzon WL, Strynadka K, Lakey JR, Rajotte RV (1996) Human pancreatic islet beta-cell destruction by cytokines involves oxygen free radicals and aldehyde production. J Clin Endocrinol Metab 81: 3197-3202.

19. Udupi V, Rice-Evans C (1992) Thiol compounds as protective agents in erythrocytes under oxidative stress. Free Radic Res Commun 16: 315-323.

20. Jez JM, Bennett MJ, Schlegel BP, Lewis M, Penning TM (1997) Comparative anatomy of the aldo-keto reductase superfamily. Biochem J $326: 625-636$.

21. Yabe-Nishimura C (1998) Aldose reductase in glucose toxicity: a potential target for the prevention of diabetic complications. Pharmacol Rev 50: 21-33.

22. Kasuya Y, Nakamura J, Hamada Y, Nakayama M, Sasaki H, et al. (1999) An aldose reductase inhibitor prevents the glucose-induced increase in PDGF-ß-receptor in cultured rat smooth muscle cells. Biochem Biophys Res Commun 261: 853-858.

23. Martín-Gallán P, Carrascosa A, Gussinye M, Domínguez C (2005) Estimation of lipoperoxidative damage and antioxidant status in diabetic children: relationship with individual antioxidants. Free Radic Res 39: 933-942.

24. Hughes H, Jaeschke H, Mitchell JR (1990) Measurement of oxidant stress in vivo. Methods Enzymol 186: 681-685.

25. Sohal RS (1993) The free radical hypothesis of aging: an appraisal of the current status. Aging (Milano) 5: 3-17.

26. Dixit BL, Balendiran GK, Watowich SJ, Srivastava S, Ramana KV, et al. (2000) Kinetic and structural characterization of the glutathione-binding site of aldose reductase. J Biol Chem 275: 21587-21595.

27. Leverve XM, Mustafa I (2002) Lactate: A key metabolite in the intercellular metabolic interplay. Crit Care 6: 284-285.

28. Vettor R, Lombardi AM, Fabris R, Pagano C, Cusin I, et al. (1997) Lactate infusion in anesthetized rats produces insulin resistance in heart and skeletal muscles. Metabolism 46: 684-690.

29. Baynes JW, Thorpe SR (1999) Role of oxidative stress in diabetic complications: a new perspective on an old paradigm. Diabetes 48: 1-9.

30. Aruoma OI, Halliwell B (1987) Superoxid-dependent and ascorbatedependent formation of hydroxyl radical from hydrogen peroxide in the presence of iron. Are lactoferrin and transferrin promoters of hydroxylradical generation? Biochem J 241: 273-278.

31. Gutteridge JM (1986) Iron promoters of the Fenton reaction and lipid peroxidation can be released from haemoglobin by peroxides. FEBS Lett 201: 291-295. 